\title{
CHANGES IN THE NUTRITIONAL VALUE OF IRRIGATED MAIZE GRAIN IN RUMINANTS DETERMINED BY FERTILIZATION
}

\author{
Rumen Bazitov, Milena Mihaylova \\ Agricultural Institute, 6000 Stara Zagora, Bulgaria \\ rumen7588@abv.bg
}

\begin{abstract}
A b st r a ct: The study was conducted in the experimental field of the Agricultural Institute in Stara Zagora under irrigation conditions on meadow - cinnamon soil with maize for grain, medium late hybrid LG 35.36 with sowing density -7000 plants per decare. The experiment includes the following four options of fertilization: opt. 1 - non-fertilized sentinel plot, opt. 2 - fertilization with $\mathrm{N}_{10} \mathrm{~kg} / \mathrm{da}$ active substance, opt.3 - fertilization with $\mathrm{N}_{15} \mathrm{~kg} / \mathrm{da}$ active substance and opt. 4 - fertilization with $\mathrm{N}_{20} \mathrm{~kg} / \mathrm{da}$ active substance. With an increase in the fertilization rate, the content of crude protein in the maize grain also increases too, with the largest increase of $20.3 \%$ compared to the unfertilized sentinel plot being the option with the highest fertilizer rate $-\mathrm{N}_{20} \mathrm{~kg} / \mathrm{da}$, followed by the option with $\mathrm{N}_{15} \mathrm{~kg} / \mathrm{da}$ active substance per decare.The content of crude fiber in the maize grain with the increasing of fertilization rate decreases by $14-30 \%$ compared to the unfertilized sentinel plot, with the least content in the option with rate $-\mathrm{N}_{10} \mathrm{~kg} / \mathrm{da}$ active substance. The content of metabolizable energy is the highest $-14.94 \mathrm{MJ} / \mathrm{kg}$ in variants 2 and $3-\mathrm{N}_{10} \mathrm{~kg} / \mathrm{da}$ and $\mathrm{N}_{15} \mathrm{~kg} / \mathrm{da}$. The FUM for all variants was $1.64 \mathrm{FUM} / \mathrm{kg}$ DM The FUG for the $\mathrm{N}_{20} \mathrm{~kg} / \mathrm{da}$ variant is 1.78 $\mathrm{FUG} / \mathrm{kg} \mathrm{DM}$, and for all other nitrogen fertilization levels it is $1.79 \mathrm{FUG} / \mathrm{kg}$ DM.The highest content of protein digestible in the intestine is expected in the option with the highest level of nitrogen fertilization$20 \mathrm{~kg}$ active substance per decare $-123 \mathrm{~g} / \mathrm{kg} \mathrm{DM}$, and for the other optionsthe values are as follows: 116 $\mathrm{g} / \mathrm{kg} \mathrm{DM} ; 119 \mathrm{~g} / \mathrm{kg} \mathrm{DM}$ and $121 \mathrm{~g} / \mathrm{kg}$ DM for a fertilization level of 0,10 and $15 \mathrm{~kg}$ of active substance of nitrogen per decare.
\end{abstract}

Key words: corn grain; $\mathrm{N}$ fertilization; energy content

\section{ПРОМЕНИ ВО ХРАНЛИВАТА ВРЕДНОСТ НА НАВОДНУВАНА ПЧЕНКА ЗА ПРЕЖИВАРИ ВО ОДНОС НА ЃУБРЕЊЕТО}

А п с т р а к т: Студијата е спроведена во експерименталното поле на Земјоделскиот институт во Стара Загора во услови на наводнување на ливада - цимет почва со пченка за жито, средно доцна хибриден LG 35,36 со густина на сеење - 7000 растенија на декар. Експериментот ги вклучува следниве четири опции на оплодување: 1 - без ѓубрење, 2 - ѓубрење со N $10 \mathrm{~kg} / \mathrm{da}$ активна супстанца, 3 - ѓубрење со $\mathrm{N}_{15} \mathrm{~kg} / \mathrm{da}$ активна супстанца и 4 ѓубрење со $\mathrm{N}_{20} \mathrm{~kg} / \mathrm{da}$ активна супстанца. Со зголемување на нивото на ѓубриво, исто така, се зголемува и содржината на суров протеин во пченката, при што најголем пораст од 20,3\% во однос на неѓубрената површина е опитот со најголемо ниво на азот во ѓубривото - $\mathrm{N}_{20} \mathrm{~kg} / \mathrm{da}$, следено со опитот со активна супстанција $\mathrm{N}_{15} \mathrm{~kg} / \mathrm{da}$. Содржината на сурови влакна во зрната со зголемување на нивото на ѓубрење се намалува за 14-30\% во однос со неѓубрената површина и повржината ѓубрена со најмалку активна супстанца $\mathrm{N}_{10} \mathrm{~kg} / \mathrm{da}$. Вредноста на метаболичка енергија е највисока $-14,94 \mathrm{MJ} / \mathrm{kg}$ во варијантите 2 и $3-\mathrm{N}_{10} \mathrm{~kg} / \mathrm{da}$ и $\mathrm{N}_{15}$ $\mathrm{kg} / \mathrm{da}$. Крмните единици за млеко (КЕМ) за сите варијанти беа $1,64 \mathrm{KEM} / \mathrm{kg}$ на сува материја. КЕМ за варијантата $\mathrm{N}_{20} \mathrm{~kg} / \mathrm{da}$ беше $1,78 \mathrm{KEM} / \mathrm{kg}$ сува материја, а за сите други варијанти со азотно ѓубриво беше 1,79 $\mathrm{KEM} / \mathrm{kg}$ сува материја. Највисоката содржина на сверливи протеини во цревата се очекува во варијантата со највисоко ниво на азот во ѓубривото - $20 \mathrm{~kg}$ активна супстанца по декар - $123 \mathrm{~g} / \mathrm{kg}$ сува материја, а за другите варијанти вредностите се како што следува: $116 \mathrm{~g} / \mathrm{kg}$ сува материја; $119 \mathrm{~g} / \mathrm{kg}$ сува материја и $121 \mathrm{~g} / \mathrm{kg}$ сува материја за површините ѓубрени со 0,10 и $15 \mathrm{~kg}$ активна супстанца азот по декар.

Клучни зборови: зрна пченка; ѓубрење со азот; енергетска вредност 


\section{INTRODUCTION}

Corn is a crop of great significance for the development of stock breeding and feeding the population (Tomov, 1984; Tsankova et al., 2006). It possesses the highest energy value among forage crops. It provides high levels of grain yield (Terziev, Yanchev, Kolev, 2001) with a well-balanced biochemical composition in terms of use as a food and feed crop (Krasteva, Bozadjiev Ilchovska, 2005, Nankov, M., L. Glogova. 2004). . The quality of corn grain is formed under the influence of several interacting factors - hybrid, environmental conditions - climate, soil conditions, and crop fertilization. (Tomov et al. 1984) In our country there have been a number of studies conducted regarding the influence of mineral fertilization as the sole factor and in complex with other agrotechnical practices on the productivity of maize for grain, under various soil and climatic conditions and types of crop rotations, with the participation of earthed-up crop (Dimitrova, FM Borisova, 2001, Nankov, Atanasov, 2001; Toncheva et al., 2006, Petrov, Georgiev, 2009). They are very limited and are mostly focused on the impact on the crop's grain yield. This implied the extension of research towards the assessment of the nutritional value of maize for grain grown under irrigated conditions in ruminants and non-ruminants.

The aim of the study was to determine the effect of different fertilization rates on the nutritional value of maize grain grown under irrigation conditions in ruminants.

\section{MATERIAL AND METHODS}

The study was conducted in the experimental field of the Agricultural Institute in Stara Zagora under irrigation conditions on meadow - cinnamon soil with maize for grain, medium late hybrid LG 35.36 with sowing density -7000 plants per decare. The soil in the experimental plot is characterized by a moderately developed humus horizon. It is poor in nitrogen $(31.3-38.1 \mathrm{mg} / \mathrm{kg}$ of soil), poorly stocked with absorbable phosphorus $(3.1-4.3 \mathrm{mg} / \mathrm{kg}$ of soil) and well stocked with absorbable potassium $(42.3-48.1 \mathrm{mg} / 100 \mathrm{~g}$ of soil). We set the experiment by the long plots method in four repetitions, with size of the harvest plot of $25 \mathrm{~m}^{2}$. The study includes the following four options of fertilization: opt. 1 - non-fertilized sentinel plot, opt. 2 - fertilization with $\mathrm{N}_{10} \mathrm{~kg} / \mathrm{da}$ active substance, opt. 3 - fertilization with $\mathrm{N}_{15} \mathrm{~kg} / \mathrm{da}$ active substance and opt. 4 - fertilization with $\mathrm{N}_{20} \mathrm{~kg} / \mathrm{da}$ active substance. Nitrogen fertilizer was applied during the vegetation of the crop in $3-5$ leaf phase, and phosphorus and potassium fertilizers in doses $\mathrm{P}_{8}$ $\mathrm{kg} / \mathrm{da}$ active substance and $\mathrm{K}_{6} \mathrm{~kg} / \mathrm{da}$ active substance with the main tillage. During the vegetation of the corn, pre-irrigation humidity of $80-85 \%$ of FC was maintained by 3 irrigations.

The chemical composition analysis of the grain was performed using the classic Weende method. The content of the main components crude protein, crude fat, crude fiber and ash - was determined. NFE was calculated using the difference of up to 100 of the listed nutrients. The energy and protein content of the feed was calculated according to the formulas of Todorov, 2007 based on the data obtained from chemical analyzes.

By the formulas of Todorov et al. $(2004,2007)$ the FUM, FUG and PDI content of ruminants were calculated.

$$
\begin{gathered}
G E=0.0242 C P+0.0366 E E+ \\
+0.0209 C F+0.017 N F E \\
M E=0.0152 D P+0.0342 D E E+ \\
+0.0128 D C F+0.0159 D N F E \\
q=M E / G E \\
F U M=M E(0.075+0.039 \mathrm{q}) \\
F U G=M E(0.04+0,1 \mathrm{q}) \\
P D I=1.11 C P(1-D e g) D s i+0.093 F O M \\
F O M=D O M-D E E-C P(1-D e g)
\end{gathered}
$$

where: $G E$ - gross energy, $C P$ - crude protein, $E E$ - ether extract, $C F$ - crude fibre, $N F E$ - nitrogen free extract, $M E$ - metabolizable energy, $D P-$ digestible protein, $D E E$ - digestible ether extract, $D F$ - digestible fibre, $D N F E$ - digestible nitrogen free extract, $D e g$ - degradability of dietary protein in the rumen, FOM - fermentable organic matter, DOM digestible organic matter, $P D I$ - protein digestible in (small) intestine, $D s i$ - digestibility in small intestine, Deg - degradability of dietary protein in the rumen.

\section{RESULTS}

In Table 1 are represented the data from the laboratory analyzes of grain maize at different levels of fertilization. 
$\mathrm{T}$ a

Chemical composition, $\mathrm{g} / \mathrm{kg} D M$

\begin{tabular}{lccccc}
\hline \hline Variants & CP & Crude fat & Crude fiber & Ash & NFE \\
\hline $1-$ unfertilized & 79.2 & 49.1 & 10.8 & 14.3 & 846.6 \\
$2 .-\mathrm{N}_{10} \mathrm{~kg} / \mathrm{da}$ & 86.6 & 51.3 & 7.5 & 13.3 & 841.3 \\
$3 .-\mathrm{N}_{15} \mathrm{~kg} / \mathrm{da}$ & 90.5 & 52.8 & 9.3 & 13.1 & 834.3 \\
$4 .-\mathrm{N}_{20} \mathrm{~kg} / \mathrm{da}$ & 95.3 & 48.7 & 8.7 & 14.5 & 832.8 \\
\hline \hline
\end{tabular}

Table 2 shows the content of digestible nutrients in maize for grain at different levels of fertilization. The values of the relevant indicators are in line with the level of raw nutrients. When calculating the values of digestible nutrients, the digestibility coefficients are taken as follows: crude protein $-73 \%$, crude fat $-84 \%$, crude fiber $-71 \%$ and NFE - 93\% (Todorov, 2007).

$\mathrm{T}$ a

\section{Digestible organic substances, $\mathrm{g} / \mathrm{kg}$ DM}

\begin{tabular}{lcccc} 
variants & Digestible protein & Digestible fats & Digestible fibres & Digestible NFE \\
$1-$ unfertilized & 57.8 & 41.2 & 7.7 & 787.3 \\
$2-\mathrm{N}_{10} \mathrm{~kg} / \mathrm{da}$ & 63.2 & 43.1 & 5.3 & 782.4 \\
$3-\mathrm{N}_{15} \mathrm{~kg} / \mathrm{da}$ & 66.1 & 44.4 & 6.6 & 775.9 \\
$4 .-\mathrm{N}_{20} \mathrm{~kg} / \mathrm{da}$ & 70.0 & 40.9 & 6.2 & 774.5 \\
\hline \hline
\end{tabular}

It was found that the amount of digestible protein is highest in the variant with nitrogen fertilization $\mathrm{N}_{20} \mathrm{~kg} / \mathrm{da}-70.0 \mathrm{~g} / \mathrm{kg}$ DM. The increase compared to the unfertilized control is $21.1 \%$. Digestible fats range from $40.9 \mathrm{~g} / \mathrm{kg} \mathrm{DM}$ in the $\mathrm{N}_{20}$ $\mathrm{kg} / \mathrm{da}$ variant to $44.4 \mathrm{~g} / \mathrm{kg}$ DM in the $\mathrm{N}_{15} \mathrm{~kg} / \mathrm{da}$ variant. Digestible fats were found to decrease from 7.7 $\mathrm{g} / \mathrm{kg} \mathrm{DM}$ in the unfertilized control to $5.3 \mathrm{~g} / \mathrm{kg} \mathrm{DM}$ in the $\mathrm{N}_{10} \mathrm{~kg} / \mathrm{da}$ variant. The digestible NFE decreased from $787.3 \mathrm{~g} / \mathrm{kg} \mathrm{DM}$ in the unfertilized control to $774.5 \mathrm{~g} / \mathrm{kg} \mathrm{DM}$ in the $\mathrm{N}_{20} \mathrm{~kg} / \mathrm{da}$ variant.

T a b 1 e 3

Energy and protein content in $1 \mathrm{~kg} D M$

\begin{tabular}{lccccc}
\hline \hline Variants & GE & ME & PDI & FUM/ & FUG/ \\
& MJ/kg & MJ/kg & g/kg & kg & kg \\
\hline $1-$ unfertilized & 18.33 & 14.9 & 116 & 1.64 & 1.79 \\
$2-\mathrm{N}_{10} \mathrm{~kg} / \mathrm{da}$ active substance & 18.43 & 14.94 & 119 & 1.64 & 1.79 \\
$3-\mathrm{N}_{15} \mathrm{~kg} /$ da active substance & 18.5 & 14.94 & 121 & 1.64 & 1.79 \\
$4-\mathrm{N}_{20} \mathrm{~kg} /$ da active substance & 18.43 & 14.86 & 123 & 1.64 & 1.78 \\
\hline \hline
\end{tabular}

GE - gross energy; ME - metabolizable energy; FUM - forage units per milk; FUG - forage units per gain 


\section{DISCUSSION}

The introduction of $10 \mathrm{~kg}$ of active substance nitrogen per decare led to an increase in the grain crude protein content by $9.3 \%$ in $1 \mathrm{~kg} \mathrm{DM}$. In the option with fertilization with $15 \mathrm{~kg}$ of active substance per decare, an increase of the crude protein by $14.3 \%$ was detected, and at the fertilization level of $20 \mathrm{~kg}$ of active substance per decare it was increased by $20.3 \%$ compared to the unfertilized sentinel plot (Table 1). The effect of nitrogen fertilization on the content of crude fat is not one-way. The values of this indicator vary from $48.7 \mathrm{~g} \mathrm{~g} / \mathrm{kg}$ DM when fertilizing with $20 \mathrm{~kg}$ act. in per decare up to $52.8 \mathrm{~g} / \mathrm{kg} \mathrm{DM}$ in the variant with $15 \mathrm{~kg}$ active in per decare. The applied rate of fertilization has reduced the content of crude fiber in the maize grain from $10.8 \mathrm{~g} / \mathrm{kg} \mathrm{DM}$ in the unfertilized control to $7.5 \mathrm{~g} / \mathrm{kg} \mathrm{DM}$ by the application of $10 \mathrm{~kg}$ of Nitrogen active substance per decare. For the other options, these values were $9.3 \mathrm{~g} / \mathrm{kg} \mathrm{DM}$ and $8.7 \mathrm{~g} / \mathrm{kg} \mathrm{DM}$, respectively. As the fertilization rate increases, there is a decrease in the content of NFE in the maize grain. From $846.6 \mathrm{~g} / \mathrm{kg}$ $\mathrm{DM}$ in the non-fertilized variant, a decrease in NFE was found to $841.3 \mathrm{~g} / \mathrm{kg} \mathrm{DM} ; 834.3 \mathrm{~g} / \mathrm{kg} \mathrm{DM}$ and $832.8 \mathrm{~g} / \mathrm{kg}$ DM for fertilization levels of 10,15 and $20 \mathrm{~kg}$ Nitrogen active substance per decare. In other studies we conducted it was found that mineral fertilization with $\mathrm{N}_{10} \mathrm{P}_{8} \mathrm{~K}_{6}$ increases the crude protein content from 0.5 to 0.62 points. The highest content of gross energy in $1 \mathrm{~kg}$ DM grain was found in the option with the introduction of $15 \mathrm{~kg}$ of nitrogen active substance $-18.5 \mathrm{MJ} / \mathrm{kg}$. The gross energy had the lowest value in $\mathrm{kg}$ of maize grain in the unfertilized sentinel plot $-18.33 \mathrm{MJ} / \mathrm{kg}$. The values of the metabolite energy were approximately the same - about $14.9 \mathrm{MJ} / \mathrm{kg} \mathrm{DM}$ grain for all variants.

The calculated FUM for all variants was 1.64 $\mathrm{FUM} / \mathrm{kg}$ DM. The FUG for the $\mathrm{N}_{20} \mathrm{~kg} / \mathrm{da}$ variant is $1.78 \mathrm{FUG} / \mathrm{kg} \mathrm{DM}$, and for all other nitrogen fertilization levels it is $1.79 \mathrm{FUG} / \mathrm{kg}$ DM.The highest content of protein digestible in the intestine is expected in the option with the highest level of nitrogen fertilization - $20 \mathrm{~kg}$ active substance per decare $-123 \mathrm{~g} / \mathrm{kg} \mathrm{DM}$, and for the other optionsthe values are as follows: $116 \mathrm{~g} / \mathrm{kg} \mathrm{DM} ; 119 \mathrm{~g} / \mathrm{kg} \mathrm{DM}$ and $121 \mathrm{~g} / \mathrm{kg} \mathrm{DM}$ for a fertilization level of 0,10 and $15 \mathrm{~kg}$ of active substance of nitrogen per decare. In other studies we conducted it was found that mineral fertilization with $\mathrm{N}_{10} \mathrm{P}_{8} \mathrm{~K}_{6}$ increases the yield of PDI by an average of $48.3 \%$ compared to unfertilized sentinel plot (V. Bazitov, 2006). Similar are the studies of V. Bazitov (2007) in which mineral fertilization with $\mathrm{N}_{10} \mathrm{P}_{8} \mathrm{~K}_{6}$ increases the crude protein content by an average of $11.2 \%$ and fat content by $16.1 \%$ The same fertilization rate reduces the content of crude fiber by $16.4 \%$ compared to the unfertilized sentinel plot, but does not affect the content of FUM, FUG and PDI.

\section{CONCLUSIONS}

With an increase in the fertilization rate, the content of crude protein in the maize grain also increases too, with the largest increase of $20.3 \%$ compared to the unfertilized sentinel plot being the option with the highest fertilizer rate $-\mathrm{N}_{20} \mathrm{~kg} / \mathrm{da}$, followed by the option with $\mathrm{N}_{15} \mathrm{~kg} / \mathrm{da}$ active substance per decare.

The content of crude fiber in the maize grain with the increasing of fertilization rate decreases by 14-30\% compared to the unfertilized sentinel plot, with the least content in the option with rate $-\mathrm{N}_{10}$ $\mathrm{kg} / \mathrm{da}$ active substance.

The content of metabolizable energy is the highest $-14.94 \mathrm{MJ} / \mathrm{kg}$ in variants 2 and $3-\mathrm{N}_{10}$ $\mathrm{kg} / \mathrm{da}$ and $\mathrm{N}_{15} \mathrm{~kg} / \mathrm{da}$.

The FUM for all variants was $1.64 \mathrm{FUM} / \mathrm{kg}$ DM The FUG for the $\mathrm{N}_{20} \mathrm{~kg} / \mathrm{da}$ variant is 1.78 FUG/kg DM, and for all other nitrogen fertilization levels it is $1.79 \mathrm{FUG} / \mathrm{kg}$ DM.The highest content of protein digestible in the intestine is expected in the option with the highest level of nitrogen fertilization $-20 \mathrm{~kg}$ active substance per decare $-123 \mathrm{~g} / \mathrm{kg} \mathrm{DM}$, and for the other optionsthe values are as follows: $116 \mathrm{~g} / \mathrm{kg} \mathrm{DM} ; 119 \mathrm{~g} / \mathrm{kg} \mathrm{DM}$ and $121 \mathrm{~g} / \mathrm{kg} \mathrm{DM}$ for a fertilization level of 0,10 and $15 \mathrm{~kg}$ of active substance of nitrogen per decare.

\section{REFERENCES}

[1] Bazitov, V., Mihaylova, M. (2006): The effect of soil cultivation and fertilization on the yield of protein and feed units of maize grain. International science conference Stara Zagora. T. 1. Plant science.

[2] Bazitov, V., Ganchev, G., Mihaylova, M. (2007): The effect of soil cultivation and fertilization on the nutritive value of maize grain by ruminants. International science conference Stara Zagora, June 7-8, 2007.

[3] Dimitrova, F., Borisovam M. (2001): Influence of tillage and top fertilization fertilized by corn on leached resin. Soil Science Agro Chemistry and Ecology, 4-6, 229-231.

[4] Nankov, M., Atanasov, P. (2001): Influence of the methods of tillage and fertilization on the yield of maize grown in a unit with wheat and after. Plant Sciences, 1, 26-29. 
[5] Todorov, N., Ilchev, A., Georgieva, V., Girginov, D., Djouvinov, D., Penkov, D., Shindarska, Z. (2004): Animal nutrition. Textbook, UNISCORP, Sofia, $312 \mathrm{p}$.

[6] Todorov, N., Krachunov, I., Djouvinov, D., Alexandrov, A. (2007): Handbook of Animal Feeding. Matkom Sofia, 400, $\mathrm{Bg}$.

[7] Toncheva, R., Dimitrova, F., Pchelarova, H. (2006): Influence of fertilization and soil difference on the formation of corn yield. Soil Science Agrochemistry and Ecology, No 3, 29-32.

[8] Tomov, N. et al. (1984): Corn in Bulgaria. Zemizdat, Sofia.

[9] Terziev, J., Yancheva, I., Kolev, T. (2001): yield, physical properties, chemical composition and bioenergy of the grain of several hybrids of corn - II. Coll.: Jubilee scientific session "80 years of higher agronomic education in Bulgaria", AU - Plovdiv, volume XLVI, book 2, 85 - 90.
[10] Petrov, P., Georgiev, D. (2009): Effect of fertilization of various maize hybrids grown in crop rotation on carbonate chernozem. Sat. International Scientific Conference "Development of the economy and society based on knowledge", Agricultural science. Plant studies, St. Zagora, $\mathrm{CD}, 460-464$.

[11] Krasteva, A., Bozadjiev, B., Ilchovska, M. (2005): Technological characteristics of some of our hybrids and corn. Plant Sciences, 42, 125-129

[12] Nankov, M., Glogova, L. (2004): Change in yield and energy in maize for grain depending on processing and fertilization. Soil Science, Agrochemistry and Ecology, No 3, $38-41$.

[13] Tsankova, Gr., Vutkova, S., Nankov, M., Hristova, S., Georgiev, G., Georgieva, I.. (2006): Research in the field of agrotechnology and their application in the production of corn for grain in the Republic of Bulgaria. Plant Sciences, 43, $202-210$. 
